\title{
DAMPAK KETERBUKAAN PERDAGANGAN TERHADAP DISKRIMINASI UPAH GENDER: TELAAH SISTEMATIS
}

\section{Ratih Maharani Ekaningtyas}

Universitas Indonesia (UI) Depok Jawa Barat, Indonesia

Email: ratih.maharani71@alumni.ui.ac.id

\section{Abstract}

Trade openness induces the increase of competition through import channel which may lead on the decrease gender wage discrimination. On the other hand, trade openness can also increase profit through export channel which may lead on the increase of gender wage discrimination. Many studies have empirically tested the predictions. However, there is no mapping of the results. This study conducts a mapping of the existing empirical studies using systematic review method, aiming to give valid, comprehensive, and balanced fact about the impact of trade openness on gender wage discrimination. Systematic review consists of the process of identifying, evaluating, and interpreting the empirical results. The data is pooled using search engine Google Scholar, Sciencedirect, and Jstor. This study concludes that in concentrated sectors, the rise of import decreases gender wage discrimination, whereas the rise of export increases gender wage discrimination. The opposite effects are hold on competitif sectors, in which the rise of import decreases gender wage discrimination, whereas the rise of export leads to the fall of gender wage discrimination.

Keywords: gender wage discrimination; trade openness; competition

\begin{abstract}
Abstrak
Keterbukaan perdagangan memicu peningkatan persaingan melalui saluran impor yang dapat berimbas pada penurunan diskriminasi upah gender. Di sisi lain, keterbukaan perdagangan juga memicu peningkatan profit melalui saluran ekspor yang dapat berimbas pada peningkatan diskriminasi upah gender. Berbagai penelitian di dunia telah menguji prediksi teori ini secara empiris. Akan tetapi, belum terdapat pemetaan hasil penelitian tersebut. Penelitian ini melakukan pemetaan terhadap hasil penelitian empiris dengan metode telaah sistematis dengan tujuan memberikan fakta yang valid, komperhensif, dan berimbang terkait dampak keterbukaan perdagangan terhadap diskriminasi upah gender. Proses telaah sistematis meliputi identifikasi, evaluasi, dan interpretasi terhadap hasil penelitian empiris. Pencarian data dilakukan dengan menggunakan mesin telusur Google Scholar, Sciencedirect, dan Jstor. Penelitian ini menyimpulkan bahwa di sektor terkonsentrasi, peningkatan impor mengurangi diskriminasi upah gender, sedangkan peningkatan ekspor meningkatkan diskriminasi upah gender. Hal sebaliknya berlaku di sektor kompetitif, dimana peningkatan impor meningkatkan diskriminasi upah gender, sedangkan peningkatan ekspor mengurangi diskriminasi upah gender.
\end{abstract}

$\begin{array}{ll}\text { How to cite: } & \text { Ekaningtyas, Ratih Maharani (2021) Dampak Keterbukaan Perdagangan Terhadap Diskriminasi Upah } \\ & \text { Gender: Telaah Sistematis. Syntax Literate. 6(5). http://dx.doi.org/10.36418/syntax-literate.v6i5.1211 } \\ \text { E-ISSN: } & \text { 2548-1398 } \\ \text { Published by: } & \text { Ridwan Institute }\end{array}$


Kata Kunci: diskriminasi upah gender; keterbukaan perdagangan; persaingan

\section{Pendahuluan}

Sejak tahun 1990an, para ekonom telah meneliti fenomena perbedaan upah gender di berbagai pasar kerja dunia untuk mengungkap penyebab rendahnya upah perempuan dibandingkan laki-laki. Terdapat argumen bahwa hal tersebut bisa disebabkan oleh perbedaan preferensi pekerjaan dan modal manusia perempuan yang cenderung rendah (Ahmed \& Mcgillivray, 2015); (Caliendo et al., 2017). Akan tetapi, mayoritas ekonom setuju bahwa diskriminasi upah gender memiliki peran yang paling substansial terhadap terjadinya perbedaan upah gender (Deshpande et al., 2018); (Fisher et al., 2021); (Laili \& Damayanti, 2018); (Zhao et al., 2019). Diskriminasi upah gender sendiri merujuk pada situasi dimana laki-laki dan perempuan yang memiliki karakteristik produktivitas identik mendapatkan tingkat upah yang berbeda.

Teori diskriminasi Becker (Lang \& Spitzer, 2020) menyebutkan bahwa diskriminasi upah dapat terjadi karena dua alasan. Pertama, perusahaan memiliki preferensi terhadap kelompok demografis tertentu, atau taste-based discrimination. Kedua, perusahaan tidak memiliki informasi yang sempurna mengenai karakteristik individu, sehingga memiliki stereotip berdasarkan kelompok demografisnya, atau statistical discrimination). Perusahaan yang tidak menyukai kelompok pekerja tertentu (misalnya perempuan) akan menanggung disutilitas ketika berinteraksi dengan kelompok tersebut. Sebagai hasilnya, perusahaan yang memaksimisasi utilitas akan membayar upah kelompok tersebut (perempuan) lebih rendah daripada upah kelompok lain (laki-laki).

Pada periode yang sama dengan fenomena perbedaan upah gender, kebijakan perdagangan internasional tengah mengalami perubahan tren. Sepanjang tahun 1950 sampai dengan 1970, kebijakan perdagangan yang populer cenderung protektif dan restriktif (Edwards, 1993). Meskipun demikian ada sekelompok ekonom yang telah membuktikan bahwa negara yang lebih terbuka terhadap perdagangan internasional memiliki performa ekonomi yang lebih unggul, terutama di negara berkembang. Baru setelah tahun 1980an, ekonom mulai merekomendasikan strategi pengembangan berbasis pasar. Dalam aplikasinya, hal tersebut dilakukan dengan menghapus hambatan perdagangan dan membuka perekonomian terhadap persaingan internasional. Hambatan perdagangan yang dimaksud meliputi tarif, pajak, kuota, dan perizinan

Adanya efek peningkatan persaingan membuat ekonom berargumen bahwa keterbukaan perdagangan dapat mengurangi diskriminasi upah gender. Argumen ini dilandaskan pada teori diskriminasi Becker yang mengemukakan bahwa perusahaan diskriminatif harus mengorbankan sebagian profitnya untuk membayar biaya diskriminasi. Pada pasar persaingan tidak sempurna, perusahaan memiliki profit positif sehingga dapat mempertahankan perilaku diskriminasi. Jika terjadi peningkatan persaingan secara eksogenus, misalnya akibat dari keterbukaan perdagangan, perusahaan tidak lagi memiliki profit positif. Dalam jangka panjang, perusahaan diskriminatif akan keluar dari pasar karena tidak mampu bersaing. Dalam jangka 
pendek, perusahaan yang ingin mempertahankan eksistensinya akan mengurangi perilaku diskriminasi. Akibatnya diskriminasi upah gender berkurang.

Di sisi lain, keterbukaan perdagangan juga dapat meningkatkan diskriminasi upah gender melalui efek ukuran pasar (Yahmed, 2017). Keterbukaan perdagangan menawarkan pangsa pasar baru bagi perusahaan melalui aktivitas ekspor. Bagi perusahaan yang memiliki keunggulan biaya dan persaingan di pasar domestik yang rendah, kesempatan ekspor dapat meningkatkan profit. Jika hanya perusahaan nondiskriminatif yang memiliki kesempatan ekspor, peningkatan profit akan mengurangi diskriminasi upah gender. Akan tetapi, jika perusahaan diskriminatif juga memiliki kesempatan ekspor, peningkatan profit akan membuat kemampuan perusahaan melakukan diskriminasi meningkat.

Beberapa penelitian telah menguji prediksi teori tersebut secara empiris menggunakan metode difference-in-differences. Penelitian-penelitian empiris yang dimaksud adalah (Alazzawi, 2014); (Artecona \& Cunningham, 2002); (Black \& Brainerd, 2004); (Kongar, 2006); (Yahmed, 2017). Selain perbedaan konteks perekonomian, penelitian-penelitian tersebut juga memiliki perbedaan dalam mengukur keterbukaan perdagangan. Pada saluran impor, pengukuran yang digunakan antara lain: perubahan tarif, kuota, rasio penetrasi impor, rasio penetrasi industri, share impor, indeks keterbukaan perdagangan, dan tekanan produk asing. Pada saluran ekspor, pengukuran yang digunakan antara lain: perubahan share ekspor dan peluang profit di pasar asing. Akibatnya, hasil penelitian pun menjadi beragam.

Adanya keragaman tersebut menyebabkan perlunya suatu pemetaan terhadap hasil penelitian yang ada. Salah satu metode pemetaan yaitu telaah sistematis (systematic review). Telaah sistematis adalah metode penelaahan penelitian terkait pertanyaan penelitian tertentu dengan menetapkan suatu standar dan kriteria, dilakukan secara terstruktur, dan direncanakan sebelum pelaksanaan sintesis (Tutik \& Hariyati, 2010). Menurut (Latifah \& Ritonga, 2020), telaah sistematis memiliki keunggulan untuk memperoleh fakta yang valid dan dapat diterapkan untuk menjawab masalah penelitian yang spesifik. Sejalan dengan Latifah dan Ritonga, (Siswanto, 2010) mengatakan bahwa telaah sistematis menghasilkan fakta yang komperhensif dan berimbang sehingga dapat digunakan dengan mudah oleh penentu kebijakan.

Penelitian ini menggunakan telaah sistematis untuk memberikan fakta yang valid, komperhensif, dan berimbang terkait dampak keterbukaan perdagangan terhadap diskriminasi upah gender. Sepanjang pengetahuan peneliti, hal ini belum pernah ditemukan pada literatur terdahulu. Adapun literatur serupa yaitu (Papyrakis et al., 2012) yang melakukan pemetaan terkait dampak keterbukaan perdagangan terhadap perbedaan upah gender. Konsep perbedaan upah gender mengakui adanya faktor-faktor selain diskriminasi yang dapat membuat upah pria dan wanita menjadi berbeda. Dengan kata lain, perbedaan upah gender merupakan fenomena yang lebih luas dibandingkan diskriminasi upah gender. Oleh karena itu, hasil penelitian (Papyrakis et al., 2012) belum mampu menggambarkan dampak keterbukaan perdagangan terhadap diskriminasi upah gender. 


\section{Metode Penelitian}

Untuk mengetahui dampak keterbukaan perdagangan terhadap diskriminasi upah gender, penelitian ini menggunakan metode telaah sistematis. Proses telaah sistematis meliputi identifikasi, evaluasi, dan interpretasi terhadap hasil penelitian terdahulu yang relevan. Ada dua jenis kriteria dalam telaah sistematis, yaitu kriteria inklusi dan eksklusi. Kriteria inklusi dalam penelitian ini yaitu artikel yang meneliti dampak keterbukaan perdagangan terhadap diskriminasi upah gender yang ditulis dalam Bahasa Inggris menggunakan metode difference-in-differences (DID). Sementara itu, kriteria eksklusi dalam penelitian ini yaitu: artikel berupa telaah pustaka, kerangka teoritis, meta-analisis, atau meta-sintesis; artikel yang tidak menggunakan Bahasa Inggris; dan artikel yang badan teksnya tidak ditampilkan secara utuh (tidak fulltext). Penelusuran penelitian menggunakan Google Scholar, ScienceDirect, dan Jstor dengan kata kunci gender wage discrimination, trade openness, trade liberalization, dan international trade. Tidak ada limitasi terhadap tahun terbit artikel.

\section{Hasil dan Pembahasan}

Berdasarkan hasil penelusuran mesin pencarian, penelitian ini mengidentifikasi 511 artikel yang bersumber dari Google Scholar (142), ScienceDirect (228), dan Jstor (141). Penelitian ini kemudian mengeluarkan 500 artikel yang tidak sesuai dengan fokus penelitian sehingga tersisa 11 artikel yang sesuai fokus penelitian. Dari 11 artikel tersebut, penelitian ini mengeluarkan 1 artikel yang berupa meta-sintesis dan 4 artikel yang tidak menggunakan konsep DID. Hasilnya, terdapat 5 artikel yang selanjutnya digunakan dalam proses sintesis pada penelitian ini. Proses seleksi artikel secara lengkap tersaji pada Tabel 1 .

\section{Tabel 1}

Proses Seleksi Artikel

\begin{tabular}{lcccc}
\hline Proses & GoogleScholar & ScienceDirect & Jstor & Total \\
\hline Hasil penelusuran mesin & 142 & 228 & 141 & 511 \\
\hline Sesuai dengan fokus penelitian & 7 & 1 & 3 & 11 \\
\hline Fulltext & 7 & 1 & 3 & 11 \\
\hline Bukan telaah pustaka dst & 6 & 1 & 1 & 10 \\
\hline Menggunakan konsep DID & 1 & 1 & 3 & 5 \\
\hline Hasil akhir & $\mathbf{1}$ & $\mathbf{1}$ & $\mathbf{3}$ & $\mathbf{5}$ \\
\hline
\end{tabular}

Tabel 2 menyajikan informasi karakteristik umum artikel. Berdasarkan fokus geografis, sebanyak 1 artikel merupakan penelitian empiris di negara berkembang, yaitu penelitian (Artecona \& Cunningham, 2002) di Meksiko. Sementara itu, 4 artikel lainnya merupakan penelitian empiris di negara maju, yaitu (Black \& Brainerd, 2004) dan (Kongar, 2006b) di US, (Alazzawi, 2014) di Mesir, dan (Yahmed, 2017) di Uruguay. Tahun penelitian bervariasi antara tahun 1976 dan 2010, baik dalam segi rentang waktu pengamatan maupun dalam segi pemilihan tahun. Hal ini disebabkan karena periode keterbukaan perdagangan berbeda-beda antar negara. Satuan analisis adalah sektor manufaktur. Jumlah sampel memiliki rentang antara 14 (Alazzawi, 2014) dan 96 
(Yahmed, 2017). Keterbukaan perdagangan yang digunakan secara umum dapat dikelompokkan menjadi dua sisi, yaitu impor dan ekspor. Pada sisi impor, proksi yang digunakan yaitu perubahan tarif, perubahan rasio penetrasi impor, perubahan share impor, perubahan kuota, indeks keterbukaan perdagangan, tekanan persaingan asing, dan keterbukaan perdagangan daerah. Pada sisi ekspor, proksi yang digunakan yaitu perubahan share ekspor dan peluang profit di pasar asing.

Tabel 2

Karakteristik Umum Artikel

\begin{tabular}{|c|c|c|c|c|c|c|}
\hline No & $\begin{array}{c}\text { Proksi } \\
\text { keterbukaan } \\
\text { perdagangan }\end{array}$ & $\begin{array}{l}\text { Jumlah } \\
\text { sampel }\end{array}$ & $\begin{array}{l}\text { Satuan } \\
\text { analisis }\end{array}$ & $\begin{array}{c}\text { Tahun } \\
\text { penelitian }\end{array}$ & $\begin{array}{c}\text { Fokus } \\
\text { geografis }\end{array}$ & Peneliti \\
\hline \multirow[t]{3}{*}{$\mathbf{1}$} & Perubahan tarif & 67 & \multirow{3}{*}{$\begin{array}{c}\text { Sektor } \\
\text { manufaktur }\end{array}$} & \multirow[t]{3}{*}{ 1987-1993 } & \multirow[t]{3}{*}{ Meksiko } & \multirow{3}{*}{$\begin{array}{l}\text { (Artecona \& } \\
\text { Cunningham, } \\
\text { 2002) }\end{array}$} \\
\hline & $\begin{array}{l}\text { Perubahan rasio } \\
\text { penetrasi impor }\end{array}$ & 34 & & & & \\
\hline & Perubahan kuota & 69 & & & & \\
\hline 2 & $\begin{array}{l}\text { Perubahan share } \\
\text { impor }\end{array}$ & 63 & $\begin{array}{c}\text { Sektor } \\
\text { manufaktur }\end{array}$ & 1976-1993 & US & $\begin{array}{l}\text { (Black \& } \\
\text { Brainerd, } \\
\text { 2004) }\end{array}$ \\
\hline 3 & $\begin{array}{l}\text { Perubahan share } \\
\text { impor }\end{array}$ & 61 & $\begin{array}{c}\text { Sektor } \\
\text { manufaktur }\end{array}$ & 1976-1993 & US & $\begin{array}{l}\text { (Kongar, } \\
\text { 2006) }\end{array}$ \\
\hline 4 & $\begin{array}{l}\text { Perubahan tarif, } \\
\text { perubahan rasio } \\
\text { penetrasi impor, } \\
\text { perubahan share } \\
\text { ekspor, perubahan } \\
\text { indeks keterbukaan } \\
\text { perdagangan, } \\
\text { perubahan } \\
\text { penetrasi industri }\end{array}$ & 14 & $\begin{array}{c}\text { Sektor } \\
\text { manufaktur }\end{array}$ & 1998-2006 & Mesir & $\begin{array}{l}\text { (Alazzawi, } \\
\text { 2014) }\end{array}$ \\
\hline 5 & $\begin{array}{lr}\text { Peluang } & \text { profit di } \\
\text { pasar } & \text { asing } \\
\text { (ekspor), tekanan } \\
\text { persaingan produk } \\
\text { asing (impor) }\end{array}$ & 96 & $\begin{array}{c}\text { Sektor } \\
\text { manufaktur }\end{array}$ & $1983-2003$ & Uruguay & $\begin{array}{l}\text { (Yahmed, } \\
\text { 2017) }\end{array}$ \\
\hline
\end{tabular}

Seluruh artikel yang tercantum pada Tabel 2 menggunakan metode empiris yang mengacu pada konsep DID. Konsep DID merupakan teknik statistik untuk mengkaji perbedaan efek pada grup yang diberi perlakuan (treatment group) dan grup kontrol (control group). Dalam konteks penelitian ini, konsep DID digunakan untuk mengontrol dua hal, yaitu: (i) mengontrol perubahan antar tahun yang bukan akibat dari keterbukaan perdagangan, dan (ii) mengontrol perubahan diskriminasi yang merupakan hasil dari peningkatan persaingan, namun tidak berhubungan dengan market power (Artecona \& Cunningham, 2002). Konsep DID dapat dituliskan sebagai berikut:

[trade impacted - nontrade impacted $]_{\text {concentrated }}$

\footnotetext{
- [trade impacted - nontrade impacted $]_{\text {competitive }}$
} 
Paruh pertama pada persamaan (1) menunjukkan dampak keterbukaan perdagangan terhadap diskriminasi upah gender di sektor terkonsentrasi, atau sektor yang memiliki market power besar. Paruh kedua pada persamaan (1) menunjukkan dampak keterbukaan perdagangan terhadap diskriminasi upah gender di sektor kompetitif, atau sektor yang memiliki market power kecil. Konsep DID pada persamaan (1) ekuivalen dengan menguji persamaan empiris (2):

$$
\Delta \operatorname{Gap}_{t i}=\beta_{0}+\beta_{1} \text { mpower }_{i}+\beta_{2} \Delta \text { trade }_{t i}+\beta_{3} \Delta \text { trade }_{t i} * \text { mpower }+\beta_{4} \Delta \delta_{t i}+\varepsilon_{i}
$$

Dimana $\Delta G a p_{t i}$ adalah perubahan perbedaan upah gender residual. Perubahan perbedaan upah residual diperoleh dari hasil dekomposisi estimasi persamaan upah lakilaki dan perempuan dengan mengontrol serangkaian karakteristik produktivitas, meliputi pendidikan, pengalaman, pengalaman kuadrat, jabatan, status perkotaan, dan karakteristik wilayah. mpower $_{\tilde{i}}$ adalah market power atau kemampuan suatu sektor dalam menentukan tingkat harga. Market power berkorelasi positif dengan profit. Dengan kata lain, semakin tinggi market power, kemampuan sektor dalam melakukan diskriminasi semakin tinggi. $\Delta$ trade $_{t i}$ adalah perubahan proksi keterbukaan perdagangan. $\Delta$ trade $_{t i} *$ mpower adalah variabel interaksi yang menunjukkan efek keterbukaan perdagangan pada sektor dengan market power besar (terkonsentasi). $\Delta \delta_{\mathrm{ti}}$ adalah variabel kontrol lain yang digunakan dalam penelitian. $\varepsilon_{\mathrm{i}}$ adalah error term.

Tabel 3

Hasil Uji Empiris Koefisien $\beta_{1}$

\begin{tabular}{|c|c|c|c|}
\hline Prediksi & Signifikansi & Proksi Keterbukaan Perdagangan & Peneliti \\
\hline \multirow{8}{*}{$>0$} & $\mathrm{x}$ & Perubahan tarif & 1,4 \\
\hline & $\mathrm{x}$ & Perubahan kuota & 1 \\
\hline & $\mathrm{v}$ & Perubahan rasio penetrasi impor & 2,4 \\
\hline & $\mathrm{v}$ & Perubahan share impor & 3 \\
\hline & $\mathrm{v}$ & Perubahan share ekspor & 4 \\
\hline & $\mathrm{x}$ & Perubahan indeks keterbukaan perdagangan & 4 \\
\hline & $\mathrm{V}$ & Perubahan penetrasi industri & 4 \\
\hline & $\mathrm{V}$ & $\begin{array}{l}\text { Peluang profit di pasar asing (ekspor), tekanan } \\
\text { persaingan produk asing }\end{array}$ & 5 \\
\hline$<0$ & $\mathrm{x}$ & Perubahan rasio penetrasi impor & 1 \\
\hline
\end{tabular}

Tabel 3 menyajikan hasil uji empiris koefisien $\beta_{1}$ yaitu dampak market power terhadap perubahan diskriminasi upah gender. Terdapat 10 hasil uji empiris yang menunjukkan nilai koefisien $\beta_{1}$ positif. Koefisien positif sejalan dengan hasil prediksi teoritis, dimana peningkatan market power memperlebar diskriminasi upah gender di suatu sektor. Dari 10 hasil uji empiris yang bernilai positif, sebanyak 6 di antaranya signifikan, sedangkan 4 sisanya tidak signifikan secara statistik. (Artecona \& Cunningham, 2002) melakukan uji sensitivitas dengan membuang data outlier. Hasil uji 
sensitivitas memberikan prediksi yang konsisten dengan hasil uji empiris sebelum uji sensitivitas, namun signifikansi berubah. Artinya, data outlier tidak mengubah hasil uji empiris, akan tetapi signifikansi sangat sensitif terhadap perubahan data. Kemungkinan hal ini disebabkan pengurangan degree of freedom dari sampel yang kecil. Dari Tabel 3 terdapat pula 1 hasil uji empiris yang menunjukkan nilai koefisien $\beta_{1}$ negatif. Koefisien negatif tidak sejalan dengan prediksi teoritis. Akan tetapi, (Artecona \& Cunningham, 2002) menilai bahwa hal ini kemungkinan disebabkan oleh permasalahan empiris, yaitu mengeluarkan sektor-sektor yang terkonsentrasi dan mengalami peningkatan diskriminasi upah gender akibat keterbatasan data.

Tabel 4

Hasil Uji Empiris Koefisien $\boldsymbol{\beta}_{2}$

\begin{tabular}{|c|c|c|c|}
\hline Prediksi & Signifikansi & Proksi Keterbukaan Perdagangan & Peneliti \\
\hline \multicolumn{4}{|c|}{ Saluran impor } \\
\hline \multirow{7}{*}{$>0$} & $\mathrm{x}$ & Perubahan rasio penetrasi impor & 1 \\
\hline & $\mathrm{v}$ & Perubahan rasio penetrasi impor & 2,4 \\
\hline & $\mathrm{V}$ & Perubahan share impor & 3 \\
\hline & $\mathrm{x}$ & Perubahan tarif & 4 \\
\hline & $\mathrm{x}$ & Perubahan indeks keterbukaan perdagangan & 4 \\
\hline & $\mathrm{v}$ & Perubahan penetrasi industri & 4 \\
\hline & $\mathrm{V}$ & Tekanan persaingan produk asing & 5 \\
\hline \multirow[t]{2}{*}{$<0$} & $\mathrm{x}$ & Perubahan tarif & 1 \\
\hline & $\mathrm{x}$ & Perubahan kuota & 1 \\
\hline \multicolumn{4}{|c|}{ Saluran Ekspor } \\
\hline \multirow[t]{2}{*}{$<0$} & $\mathrm{v}$ & Perubahan share ekspor & 4 \\
\hline & $\mathrm{v}$ & Peluang profit di pasar asing (ekspor) & 5 \\
\hline
\end{tabular}

Tabel 4 menyajikan hasil uji empiris koefisien $\beta_{2}$ yaitu dampak keterbukaan terhadap perubahan diskriminasi upah gender di sektor kompetitif. Pada saluran impor, terdapat 8 hasil uji empiris yang menunjukkan nilai koefisien $\beta_{2}$ positif. Koefisien positif berarti peningkatan impor memperlebar diskriminasi upah gender di sektor kompetitif. Hasil ini tampak berbeda dari prediksi teoritis. (Black \& Brainerd, 2004) berargumen bahwa laki-laki cenderung berkontribusi sebagai pekerja trampil, sedangkan perempuan sebagai pekerja kurang trampil. Ketika keterbukaan perdagangan membawa bias terhadap pekerja trampil, upah premium laki-laki akan meningkat dan hal ini membuat perbedaan upah gender di sektor kompetitif semakin melebar. Sementara itu, (Kongar, 2006) memberikan alternatif interpretasi terhadap fenomena ini. Dalam menghadapi peningkatan persaingan akibat keterbukaan perdagangan, sektor kompetitif melakukan substitusi pekerja laki-laki dengan perempuan yang berupah lebih rendah untuk mengurangi biaya pekerja. Peningkatan jumlah pekerja perempuan berupah rendah membuat rata-rata upah perempuan menjadi rendah. Akibatnya, perbedaan upah gender secara umum melebar.

Dari 7 hasil uji empiris yang bernilai positif, 4 di antaranya signifikan secara statistik, sedangkan 3 lainnya tidak signifikan. Uji sensitivitas yang dilakukan (Black \& 
Brainerd, 2004) dan (Yahmed, 2017) menunjukkan konsistensi dengan hasil uji empiris sebelum uji sensitivitas. Dengan kata lain, signifikansi hasil uji empiris dipengaruhi oleh ukuran sampel penelitian. Dari Tabel 4, terdapat pula 2 hasil uji empiris yang menunjukkan nilai koefisien $\beta_{2}$ negatif. Koefisien negatif berarti peningkatan keterbukaan perdagangan mengurangi diskriminasi upah gender di sektor kompetitif, yang mana sejalan prediksi teori Becker. Meskipun demikian, hasil ini tidak signifikan secara statistik.

Pada saluran ekspor, kedua penelitian menunjukkan nilai koefisien $\beta_{2}$ negatif dan signifikan secara statistik. Koefisien negatif berarti peningkatan ekspor mengurangi diskriminasi upah gender di sektor kompetitif. (Yahmed, 2017) menilai bahwa ekspor mengekspos suatu industri terhadap persaingan yang lebih ketat. Hal ini bersinonim dengan berkurangnya market power pada sektor yang melakukan ekspor. Ketika market power berkurang, sesuai dengan prediksi teoritis Becker, diskriminasi upah gender pun berkurang.

Tabel 5

Hasil Uji Empiris Koefisien $\boldsymbol{\beta}_{3}$

\begin{tabular}{|c|c|c|c|}
\hline Prediksi & Signifikansi & Proksi Keterbukaan Perdagangan & Peneliti \\
\hline \multicolumn{4}{|c|}{ Saluran impor } \\
\hline \multirow[b]{4}{*}{$<0$} & $\mathrm{x}$ & Perubahan rasio penetrasi impor & 1 \\
\hline & $\mathrm{V}$ & Perubahan rasio penetrasi impor & $2,3,4$ \\
\hline & $\mathrm{x}$ & Perubahan rasio penetrasi industri & 4 \\
\hline & $\mathrm{v}$ & Tekanan persaingan produk asing & 5 \\
\hline \multirow{4}{*}{$>0$} & $\mathrm{x}$ & Perubahan tarif & 1 \\
\hline & $\mathrm{x}$ & Perubahan kuota & 1 \\
\hline & $\mathrm{x}$ & Perubahan tarif & 4 \\
\hline & $\mathrm{x}$ & Perubahan indeks keterbukaan perdagangan & 4 \\
\hline \multicolumn{4}{|c|}{ Saluran Ekspor } \\
\hline \multirow[t]{2}{*}{$>0$} & $\mathrm{x}$ & Perubahan share eskpor & 4 \\
\hline & $\mathrm{v}$ & Peluang profit di pasar asing (ekspor) & 5 \\
\hline
\end{tabular}

Tabel 5 menyajikan hasil uji empiris koefisien $\beta_{3}$ yaitu dampak keterbukaan perdagangan terhadap diskriminasi upah gender di sektor terkonsentrasi. Pada saluran impor, terdapat 6 hasil uji empiris yang menunjukkan koefisien $\beta_{3}$ negatif. Koefisien negatif berarti peningkatan impor mengurangi diskriminasi upah gender di sektor terkonsentrasi. Hasil ini sejalan dengan prediksi teoritis yang mengimplikasikan peningkatan persaingan akibat impor akan mengurangi market power di suatu sektor. Ketika market power berkurang, yang ekuivalen dengan berkurangnya profit, suatu kemampuan suatu sektor dalam melakukan diskriminasi upah gender juga menjadi berkurang. Meskipun demikian, (Kongar, 2006) menyoroti bahwa berkurangnya diskriminasi upah gender bisa jadi disebabkan oleh berkurangnya pekerja perempuan yang berupah rendah. Dalam menghadapi peningkatan persaingan, suatu sektor dapat melakukan penyesuaian biaya dengan mengurangi jumlah pekerja. Jika yang dikurangi adalah perempuan berupah rendah, upah rata-rata perempuan yang tersisa di pasar kerja meningkat. Hasilnya, diskriminasi upah gender seolah-olah berkurang. Dari 6 hasil uji 
empiris dengan koefisien positif, sebanyak 4 di antaranya signifikan, sedangkan 2 lainnya tidak signifikan secara statistik. Hal ini kemungkinan disebabkan oleh ukuran sampel.

Sementara itu, terdapat 4 hasil uji empiris yang menunjukkan koefisien $\beta_{3}$ positif, meskipun tidak signifikan secara statistik. Koefisien positif berarti peningkatan impor meningkatkan diskriminasi upah gender di sektor terkonsentrasi. Hasil ini tidak sesuai dengan prediksi teoritis. Ada dua kemungkinan yang menyebabkan hasil tersebut. Pertama, permasalahan empiris yang muncul akibat mengeluarkan sektor-sektor penting, yaitu sektor terkonsentrasi yang mengalami penurunan diskriminasi upah gender. Kedua, proksi keterbukaan perdagangan yang digunakan, yaitu perubahan tarif dan kuota, memiliki pengaruh tidak langsung terhadap market power di suatu sektor.

Pada saluran ekspor, kedua penelitian menunjukkan nilai koefisien $\beta_{3}$ positif dan signifikan secara statistik. Koefisien positif berarti peningkatan ekspor memperlebar diskriminasi upah gender di sektor terkonsentrasi. Hasil ini sejalan dengan prediksi (Yahmed, 2017) yang berargumen bahwa ekspor dapat membuka peluang peningkatan profit. Ketika sektor terkonsentrasi dapat memasuki pasar ekspor sedemikian hingga profitnya meningkat, kemampuan sektor tersebut dalam melakukan diskriminasi akan meningkat. Hasilnya, diskriminasi upah gender di sektor terkonsentrasi melebar.

\section{Kesimpulan}

Berdasarkan hasil analisis terhadap 5 penelitian yang relevan, penelitian ini menyimpulkan bahwa keterbukaan perdagangan meningkatkan diskriminasi upah gender di sektor kompetitif melalui saluran impor. Terdapat dua hal yang ditengarai dapat menyebabkan hasil ini. Pertama, keterbukaan perdagangan memiliki bias terhadap pekerja trampil, sehingga meningkatkan upah premium laki-laki yang merupakan pekerja yang relatif terampil dibandingkan perempuan. Peningkatan upah premium pria menyebabkan perbedaan upah gender secara umum semakin melebar. Kedua, peningkatan persaingan akibat tekanan impor mendorong perusahaan melakukan substitusi pekerja laki-laki dengan pekerja perempuan yang upahnya relatif lebih murah. Akibatnya, rata-rata upah perempuan menurun dan perbedaan upah gender secara umum semakin melebar. Di sisi lain, keterbukaan perdagangan mengurangi diskriminasi upah gender di sektor kompetitif melalui saluran ekspor. Suatu sektor terekspos pada persaingan yang lebih ketat ketika memasuki pasar asing. Ketatnya persaingan membuat sektor tersebut tidak lagi dapat menanggung biaya diskriminasi yang mahal. Hal ini menyebabkan diskriminasi upah gender di sektor kompetitif berkurang.

Sementara itu, keterbukaan perdagangan mengurangi diskriminasi upah gender di sektor terkonsentrasi melalui saluran impor. Hasil ini sejalan dengan implikasi teori Becker yaitu peningkatan persaingan secara eksogenus, misalnya akibat peningkatan impor, akan mengurangi kemampuan sektor dalam melakukan diskriminasi. Meskipun demikian, fenomena ini juga bisa disebabkan oleh berkurangnya pekerja perempuan berupah rendah. Ketika peningkatan persaingan mendorong pengurangan pekerja perempuan berupah rendah, rata-rata upah perempuan yang tersisa di pasar kerja 
meningkat. Hal ini menciptakan efek yang sama dengan berkurangnya perilaku diskriminasi upah gender di pasar kerja. Pada saluran ekspor, keterbukaan perdagangan meningkatkan diskriminasi upah gender di sektor terkonsentrasi. Ekspor tidak hanya mengekspos sektor pada persaingan, namun juga memberikan peluang peningkatan profit. Ketika suatu sektor terkonsentrasi dapat meningkatkan profitnya, kemampuan sektor tersebut dalam melakukan diskriminasi pun menjadi lebih tinggi.

Secara umum penelitian ini telah dapat menarik kesimpulan dari hasil penelitian empiris terdahulu mengenai dampak keterbukaan perdagangan terhadap diskriminasi upah gender. Akan tetapi, kesimpulan tersebut belum dapat digeneralisir karena beberapa alasan. Pertama, penelitian terdahulu cenderung representatif di negara maju, belum banyak dilakukan di negara berkembang maupun negara miskin. Kedua, keterbukaan perdagangan memiliki mekanisme yang kompleks. Proksi dan metodologi yang berbeda dapat menyebabkan hasil penelitian yang berbeda pula. Ketiga, jumlah sampel penelitian terdahulu masih tergolong kecil. Hal ini berpengaruh terhadap akurasi hasil. Oleh karena itu, penelitian ini mendorong adanya penelitian lanjutan di perekonomian yang karakteristiknya berbeda guna mendapatkan kesimpulan yang dapat berlaku secara umum. 


\section{BIBLIOGRAFI}

Ahmed, S., \& Mcgillivray, M. (2015). Human Capital , Discrimination , and the Gender Wage Gap in Bangladesh. World Development, 67, 506-524. https://doi.org/10.1016/j.worlddev.2014.10.017 Google Scholar

Alazzawi, S. (2014). Trade liberalization, industry concentration and female workers : the case of Egypt. IZA Journal of Labor Policy, 3(20), 1-30. Google Scholar

Artecona, R., \& Cunningham, W. (2002). Effects of trade liberalization on the gender wage gap in Mexico. In Policy Research Report on Gender and Development (Issue May). Google Scholar

Black, S. E., \& Brainerd, E. (2004). Importing equality? The effects of globalization on gender discrimination. Industrial and Labor Relations Review, 57(4), 540-559. Google Scholar

Caliendo, M., Lee, W., \& Mahlstedt, R. (2017). The Gender Wage Gap and the Role of Reservation Wages: New Evidence for Unemployed Workers. Journal of Economic Behavior and Organization, 136, 161-173. Google Scholar

Deshpande, A., Goel, D., \& Khanna, S. (2018). Bad Karma or Discrimination? Male Female Wage Gaps Among Salaried Workers in India. World Development, 102, 331-344. https://doi.org/10.1016/j.worlddev.2017.07.012 Google Scholar

Edwards, S. (1993). Openness, Trade Liberalization, and Growth in Developing Countries. Journal of Economic Literature, 31(3), 1358-1393. Google Scholar

Fisher, B., Biyase, M., Kirsten, F., \& Rooderick, S. (2021). Gender Wage Discrimination in South Africa within the Affirmative Action Framework Gender Wage Discrimination in South Africa within the. Journal of Developing Areas, 55(2). Google Scholar

Kongar, E. (2006a). Importing Equality or Exporting Jobs?: Competition and Gender Wage and Employment Difference in US Manufacturing. Working Paper 06-7. Salt Lake City: International Working Group on Gender .... Google Scholar

Kongar, E. (2006b). Importing equality or exporting jobs? Competition and gender wage and employment differentials in U.S. manufacturing. The Levy Economicss Institute of Bard College Working Paper, 436. Google Scholar

Laili, M. H., \& Damayanti, A. (2018). Kesenjangan upah antargender di Indonesia: Bukti empiris di sektor manufaktur. Jurnal Ekonomi Dan Pembangunan Indonesia, Edisi Khusus Call for Paper Jepi 2018, 1-21. Google Scholar

Lang, K., \& Spitzer, A. K. (2020). Race Discrimination: An Economic Perspective. Journal of Economic Perspectives, 34(2), 68-89. Google Scholar 
Latifah, L., \& Ritonga, I. (2020). Systematic Literature Review ( SLR ): Kompetensi Sumber Insani Bagi Perkembangan Perbankan Syariah Di Indonesia Daya. Al Maal: Journal of Islamic Economics and Banking, 2(1), 63-80. Google Scholar

Papyrakis, E., Covarrubias, A., \& Verschoor, A. (2012). Markets Gender and Trade Aspects of Labour Markets. The Journal of Development Studies, 48(1), 81-98. Google Scholar

Siswanto. (2010). Systematic review sebagai metode penelitian untuk mensintesis hasilhasil penelitian. Buletin Penelitian Sistem Kesehatan, 13(4), 326-333. Google Scholar

Tutik, R., \& Hariyati, S. (2010). Mengenal sistematic review theory dan studi kasus. Jurnal Keperawatan Indonesia, 13(2), 124-132. Google Scholar

Yahmed, S. Ben. (2017). Gender Wage Discrimination and Trade Openness. Prejudiced Employers in an Open Industry. ZEW Discussion Paper, 17-047, 1-53. Google Scholar

Zhao, X., Zhao, Y., Chou, L., \& Leivang, B. H. (2019). Changes in gender wage differentials in China: a regression and decomposition based on the data of CHIPS1995 - 2013. Economic Research-Ekonomska IstraA3/4ivanja, 32(1), 31623182. https://doi.org/10.1080/1331677X.2019.1660906 Google Scholar

\section{Copyright holder:}

Ratih Maharani Ekaningtyas (2021)

First publication right:

Journal Syntax Literate

This article is licensed under: 